\title{
Menghitung Etnis Jawa di Sumut
}

Oleh Shohibul Anshor Siregar

Sebuah judul berita yang tayang sejak tanggal 5 Januari lalu berbunyi demikian: "Alasan PDIP Pilih Djarot di Sumut, Megawati: "Di Sana Banyak Juga Jawanya". (https://edisimedan.com/alasan-pdip-pilih-djarot-di-sumut-megawati-di-sana-banyak-jugajawanya/). Berita itu dilengkapi sebuah foto dengan pose Megawati Soekarnoputri menyerahkan Surat Penunjukan kepada Djarot. Foto itu juga menunjukkan kehadiran orangorang berpakaian adat yang rapi. Djarot sendiri pakai kemeja lengan panjang berwarna merah bersimbolkan kepala banteng di dada kiri. Ia tak berpeci, tak memakai blankon dan tak memakai pakaian adat lainnya seperti orang-orang yang terekam berdiri di belakangnya saat deklarasi pasangan calon gubernur dan wakil gubernur di empat provinsi (Nusa Tenggara Barat, Maluku Utara, Lampung, dan Papua) itu.

Media ini pun mengutip ucapan Megawati Soekarnoputri demikian: "Ini disiarkan langsung televisi gak ya? Mudah-mudahan rakyat Sumut bisa melihat, tolonglah terima Pak Djarot. Karena di sana, banyak juga jawa-nya," saat berpidato tanpa teks di Kantor DPP PDI-P, Menteng, Jakarta, Kamis (4/1/2018)". Bagi Megawatisoekarnoputri Djarot itu orang yang bagus, orang yang bersih, orang yang sangat serius, orang yang pasti akan bisa. "..... tidak perlu panjang lebar, saya memasukkan Pak Djarot ke sana," ujar Megawati disambut pekikan "Merdeka" dari orang yang hadir pada deklarasi itu.

Awalnya, sebut media itu, Megawati Soekarnoputri merasa kesulitan menyampaikan kehendaknya itu kepada Djarot. Ia mengaku khawatir Djarot menolak untuk ditunjuk ke Sumut. Akhirnya Mega punya strategi untuk menyampaikan niatnya kepada Djarot. "Saya bilang saya Ketua Umum partai memerintahkan petugas partai, kamu mau enggak masuk Sumut. 'Siap Bu, sebagai petugas partai saya bersedia' begitu kata Pak Djarot'. Pertimbangan ini menarik untuk ditelaah. Mendalami data itulah yang akan dilakukan dalam tulisan pendek ini.

Bagaimana komposisi demografis Sumut? Barangkali data yang akan saya berikan berikut ini belum jauh berubah. Etnis Batak (tanpa membagi berdasarkan pihak-pihak yang sudah menolak disebut Batak dan yang tetap setia dengan identitas Batak), jika keseluruhannya digabungkan, menduduki jumlah mayoritas, yakni sebanyak 41.93\%. Etnis Jawa menduduki posisi mayoritas kedua, yakni sekitar 32.62\%. Etnis Nias 6.36\%, Melayu 5.92\%, Tionghoa $3.07 \%$, Minang 2.66\%, Aceh 1.03\%, Banjar 0.97\%, Banten 0.36\%, Sunda 0.27\%, Papua $0.09 \%$. Masih ada jumlah lain yang mungkin punya hak pilih, yakni etnis yang berasal dari Luar Negeri. Jumlahnya sekitar $0.23 \%$. Etnis lain yang lazimnya tetap saja ada untuk setiap sensus penduduk (etnis Lain-lain) di Sumut jumlahnya cukup besar, yakni sekitar $4.49 \%$. Tak jelas siapa-siapa saja etnis lain-lain ini. Mungkin angka ini hanya disebabkan oleh ketidakjelasan dalam proses pendataan terutama wawancara oleh para petugas lapangan. Tetapi juga kemungkinan disebabkan oleh makin banyaknya orang yang sudah susah mengidentifikasi dirinya kecuali sebagai Indonesia karena kawin-mawin antar etnis pada generasi-generasi panjang di atasnya.

Jadi kita lihat etnis Jawa menduduku jumlah terbesar kedua di Sumut, dan Djarot diidentifikasikan kepada etnis ini. Itulah salah satu dasar bagi penentuan Djarot ditugaskan menjadi calon Gubernur dari PDIP ke Sumut, sebagaimana ditegaskan dalam berita yang dikutip di atas. 
Bagaimana mengidentifikasi etnis Jawa di Sumatera secara politik? Begini. Mereka pastilah bisa dipolarisasi berdasarkan afiliasi agama dan organisasi tertentu. Keduanya variable itu pasti menjadi reference group bagi mereka sebagaimana bagi etnis lain. Pendekatan SARA ini memang tetap efektif dalam penghitungan peluang dalam suksesi. Betul kan?

Di Jawa, konon ilmuan sosial asal Amerika Clifford Geertz pernah membuat polarisasi etnis Jawa menjadi Priyayi, Abangan dan Santri. Bisakah pembagian atau kategorisasi itu digunakan untuk etnis Jawa di Sumut? Di Sumut pasti ada yang merasa dirinya Priyayi, tapi mungkin tak memiliki otoritas seperti priyayi di Jawa itu. Karena itu untuk analisis di Sumut unsur ini tak mengapa diabaikan. Tak ada stelsel kultural yang menopang secara kuat kelembagaannya di sini, setahu saya.

Memang ada berbilang, kalau bukan banyak, yang bergelar Raden Mas dari kalangan yang bermarga di sini, dan itu diperoleh hanya melalui sebuah seremoni semacam wisuda penobatan dari sebuah kerajaan di Jawa, bukan Jogjakarta. Jogjakarta tak memiliki tradisi seperti itu sama sekali. Dalam praktik keseharian setelah dinobatkan menjadi Raden Mas, mereka pun tak selalu mampu menunjukkan kewajiban moralnya sebagai orang Jawa "baru", persis seperti orang-orang Jawa atau orang mana pun itu yang dianugerahi marga di Sumut. Usai seremoni, segalanya berakhir. Ini memang sebuah tragedi budaya yang dirusak oleh orientasi politik. Jadi sekarang kita tinggal menghitung Jawa Santri dan Jawa Abangan saja. Saya harap Anda setuju.

Jawa santri secara kultural lazimnya berafiliasi dan tak jarang menjadi bagian dari "pengendali" dalam organisasi keagamaan yang ada seperti Al-Washliyah, Muhammadiyah dan NU. Juga mereka menjadi tokoh penting dan pendukung Majelis Ta'lim dan Perwiridan yang rutin setiap hari Kamis malam Jum'at. Saya merasa tak salah jika mengatakan bahwa afiliasi politiknya akan ke PKS, PAN, PBB, PPP dan tak tertutup juga di partai lain tak kecuali PDIP (Affan yang mantan Sekum PDIP Sumut adalah sedikit dari contoh santri yang diberi reward dan kedudukan bagus di partai non agamis di Sumut) meski dalam jumlah yang sangat sedikit. Bisa dihitung jarilah. Romo Raden Mohammad Syafei adalah sebuah pengecualian, seorang santri dengan atribut Jawa yang benar-benar konsisten dan memadukan tradisi kultural etnis dan hasanah keislaman. Ia ada di Partai Gerindra, setelah sebelumnya pernah menjadi tokoh dari partai politik yang sudah tidak ikut lagi pemilu.

Jawa Abangan lazimnya tampil mengaktualisasikan diri pada organisasi-organisasi etnis seperti Pujakesuma, Pendowo, FKWJ, PJB dan lain-lain. Secara politik umumnya merasa nyaman masuk ke partai-partai seperti PDIP, Golkar, Gerindra, Demokrat, NasDem dan lainlain. Wagirin Arman adalah contoh untuk Golkar. Soetarto dapat menjadi contoh untuk PDIP.

Mana jumlah paling besar dari kedua komunitas itu? Untuk tidak ceroboh kita sama ratakan saja, fifty-fifty. Saya yakin begitu, karena aktivias dakwah pencerahan yang belakangan begitu gencar melalui berbagai media dan program organisasi-organisasi dakwah telah berhasil melakukan kualitas keberagamaan kalangan abangan hingga perubahan jumlah menjadi berimbang. Selain itu ada jenis lain dari komunitas Jawa di Sumut, yakni Kejawen. Mereka seperti penganut Ugamo Malim yang berpusat dan berasal dari Tapanuli. Jumlah mereka tidak dominan meski sangat efektif mengendalikan komunitas khasnya.

Jawa Santri lebih mudah melakukan appeal kepada Jawa Abangan untuk penentuan pilihan politik karena apa yang dapat disebut sebagai otoritas dan kewibawaan ganda. Namun sebaliknya tidak ada pemimpin organisasi abangan yang cukup mampu berbuat sama kepada 
tokoh Jawa Santri dalam pilihan politik. Otoritas dan kewibawaan mereka tak sekuat yang pertama, atau, baik otoritas maupun kewibawaannya memang berbeda satu sama lain. Tetapi sebaliknya tokoh Jawa Santri dapat melakukan itu karena jamak mereka menjadi panutan di dua komunitas, katakanlah seperti Ngatidjan Toha dari Simalungun, Dalail Ahmad dari Deli Serdang, Asmuni dari Medan, As Adinata dari Binjai, dan lain-lain. Orang-orang ini cukup berpengaruh di kantong-kantong pemukiman tertentu etnis Jawa ini. Ada yang memiliki hubungan pencerahan (misalnya karena kerap menjadi ustaz untuk perayaan hari besar umat Islam atau karena kerap menghadiri acara kebudayaan seperti wayang kulit) di Medan, Deliserdang, Sergai, Langkat, Asahan, maupun di daerah-daerah transmigrasi seperti di Muara Upu, Tabuyung SP.1, Singkuang SP.1, Singkuang SP.2, Sinunukan SP, Sinunukan SP, Rawa Kolang SP 2, Paluta dan yang lain.

Apakah tak ada hitungan lain, misalnya Kristen Jawa, Katholik Jawa dan lain-lain? Ada, tapi jumlahnya tak begitu banyak. Kurang lebih berimbang dengan komunitas Kejawen. Saya tak punya data yang cukup akurat dan update tentang ini. Begitu pun tetap saja tak boleh dilewatkan dalam perhitungan kampanye pemenangan.

Dengan penetapan Djarot sebagai calon Gubernur Sumut dari PDIP bermakna partai ini tak lagi memiliki peluang untuk beroleh calon wakil dari etnis Jawa, karena Djarot dianggap mewakili aspirasi pemilih etnis Jawa dan diharapkan mampu membulatkan suara etnis Jawa. Beberapa yang namanya sudah begitu nyaring disebut sebagai bakal calon gubernur dalam pemberitaan selama ini, seperti mantan Kapoldasu Wisjnu Amatsastro, mantan pasangan Efendy Simbolon pada pilgubsu 2013 Djumiran Abdi, Ketua PJB Adi Munasib, tokoh partai Abdiyanto, dan nama-nama lain termasuk Sekretaris Umum PDIP Soetarto, kiranya sudah tak mungkin masuk dalam bursa. Mereka semua dianggap harus legowo (rela) diwakili oleh Djarot.

Dengan pertimbangan SARA atas dukungan untuk Djarot yang dikemukakan oleh Ketum PDIP Megawati Soekarnoputri dalam berita yang dikutip dalam tulisan ini, jelas sekali pemimpin tertinggi partai yang harismatik ini kurang atau tak beroleh input yang benar dari pengkaji internal PDIP dan para "pembisiknya". Tetapi langkah sudah ditetapkan, dan ini tak lagi mungkin dirubah mengingat sempitnya waktu dan juga dampak kewibawaan Ketua Umum dan partai jika sekiranya last minutes dirubah. Jika dengan langkah SARA ini nanti Djarot belum beruntung dalam pilgubsu, hendaknya janganlah ada dari pihak mana pun yang cengeng menuduh Djarot kalah sebagai korban SARA, korban intoleransi, dan tuduhantuduhan buruk tak berdasar lainnya. Tidak elok itu didengar oleh rakyat di grassroot yang selama ini kesejahteraannya tak pernah terdongkrak oleh kebijakan. Tentu saja sangat penting bagi PDIP untuk sejak dini mengantisipasi agar langkah ini tak begitu besar dampak negatifnya nanti terhadap Pemilu Serentak tahun 2019.

Apa gerangan reaksi rakyat kelak? Saya tak bermaksud menakut-nakuti. KUPD di seluruh Indonesia pun tahu kondisi apatisme rakyat kini. Rakyat di grassroot itu kian lama kian merasa tak memerlukan pemimpin formal itu, apalagi perhelatan politik seperti pilkada. Sungguh, saya bercerita jujur kepada Anda. Jawa Santri dan Jawa Abangan sama kuatnya dalam potensi untuk tak pergi ke TPS pada hari $\mathrm{H}$ pencoblosan, sama dengan pemilih dari etnis lain yang senasib (ekonomi) dan yang pada akhirnya menjadi sangat apolitis. Data rujukan bisa diambil dari pilkada kota Medan yang tercatat sebagai pilkada dengan partisipasi pemilih terendah sepanjang sejarah di Indonesia. 
Memang, evaluasi atas demokrasi sudah sangat mendesak untuk melihat sisi mana lagi dari proses demokrasi ini yang masih dapat dianggap memiliki kemanfaatan untuk rakyat dan kehidupannya. Bayangkan saja, untuk Pilkada DKI yang tercatat begitu panas dan paling seru di Indonesia sepanjang sejarah, partisipasi pemilih juga tak seperti dibayangkan. Tak sebanding dengan panasnya perhelatan itu. Risma Walikota Surabaya, Anda mengenalnya bukan? Di sana juga partisipasi pemilih tak seperti diharapkan, terutama kalau kita kaitkan dengan bagaimana media arus utama mengangkatnya begitu besar, paling berpengaruh, paling responsif dan paling merakyat.

"Di Sana Banyak Juga Jawanya", kata Megawati. Djarot pun ditetapkan menjadi calon gubsu dari PDIP untuk Sumut. Apa yang janggal? Bagi saya yang membaca sejarah serba sedikit, kini benar-benar terbayang bagaimana Soekarno berteman sangat akrab dan mempercayakan orang berdasarkan merit system dalam kabinet-kabinetnya. Anda masih ingat nama-nama non Jawa seperti Syarifuddin Harahap, Syahrir, Hatta, Mohammad Natsir, Burhanuddin Harahap, Mananti Sitompul dan lain-lain? Terasa ada yang salah. Dalam kedangkalan-kedangkalan berfikir kita barangkali. Itu sangat perlu kita koreksi sebelum zaman mengoreksinya. Setuju?

Penulis dosen FISIP UMSU. Koordinator Umum Pengembangan Basis Sosial Inisiatif \& Swadaya. Ketua Dewan Pakar DPP Forum Komunikasi Warga Jawa (FKWJ). 